\title{
Old Age Coping Strategies of the Ionian and Maltese Poor, 1800-1865
}

\author{
John Chircop
}

\section{Introduction}

A growing corpus of historical work is increasingly showing the complexity and diversity of old age, while proving that it was common for the elderly to ent European societies and periods. ${ }^{1}$ Elaborating on this accumulating historical knowledge, the present study seeks to examine the survival strategies adopted by the aging poor in response to unanticipated changes in their life circumstances, due to disability, illness or financial mishaps, and to mitigate the more predictable vulnerabilities associated with advanced old age. This means focusing attention on the daily practices and tactics employed by old men and women to acquire provisions, social assistance and medical treatment from the intersecting social nets of the household, neighbourhood and the parish, from communal and formal state charity establishments.

Most historical studies on old age point to the fundamental role, which the household and the neighbourhood played as a mainstay of social support and human care for the elderly during long-term illness. ${ }^{2}$ At the same time, on the whole, this literature corroborates Pieter Spierenburg's conception that "'a golden age' of unequivocal respect for the elderly in which children, relatives and the

1 Margareth Pelling and Richard M. Smith, eds., Life, Death and the Elderly. Historical Perspectives (London-N. York, 1991), 'Introduction', p. 23; Pat Thane, Old Age in English History: Past Experiences, Present Issues (Oxford, 2000), p. 459; Paul Johnson, 'Historical readings of Old Age and Ageing', in P. Johnson and P. Thane, eds., Old Age from Antiquity to Post-modernity (London, 1998), p. 1.

2 P. Laslett and R.Wall, Household and Family in Past time (Cambridge, 1972); Jack Resch, 'Poverty, Patriarchy and Old Age: The Households of American Revolutionary War Veterans 1820-1830', in R. Ottoway, L.A. Botelho and K. Kittredge, eds., Power and Poverty. Old Age in the Pre-Industrial Past (Connecticut-London, 2000), pp. 21-47; Susannah R. Ottoway, 'Introduction', in ibid, p. 5. 
community in general took care of their elderly 'as a matter of course' never existed". ${ }^{3}$ The present study substantiates this pragmatic outlook, while further concentrating on the roles played by the household and community as fundamental welfare nets for the aged. This is done from a perspective which attempts to be as inclusive as possible of old age differentiations existing due to social status and health condition, gender, household composition, and cultural practice.

In order to facilitate analysis through such an inclusive approach, we take on Paul Johnson's proposal to concentrate on aged people in localised social-spaces, ${ }^{4}$ from a wider comparative perspective. In this way, the elderly poor and the coping strategies they adopted are examined within the immediate social settings, in specific rural and urban landscapes, and as embedded within the broader political economies of the Ionian Protectorate and Malta. During the period under discussion, these sets of islands formed part of the British imperial maritime network in the Mediterranean, ${ }^{5}$ through which they experienced uneven economic, social and demographic developments due to their respective strategic imperial value. Accordingly, from the 1840s, Malta's central harbour district developed as the most intensively urbanised colonial zone in this imperial network, in response to this island being stepped up as the key British strategic naval-military base and trade entrepot in the Mediterranean. Corfu Town, the capital of the next most important British-controlled island in the region passed through a similar, but less intensive process of colonisation and urbanisation. This, while the remaining areas in these principal domains, and more remarkably still the remoter southern Ionian islands, remained prevalently rural and generally unaffected by the British imperial presence.

One difficulty encountered throughout this research work was the scarcity of primary sources dealing with the daily life of the elderly poor. With their vast majority unlettered, they left no written record of their ordinary activities for posterity. The problem is particularly acute for most of the period covered in this study, as official documentation and published statistics on old age issues are scarce and, when available, very fragmented. To be sure, the first inclusive census published in these British Mediterranean domains was that of Malta in 1851, and this provides important figures and indicators on the use of hospitals and formal relief by the elderly, even if for the last part of the period under review.

3 Pieter Spierenburg, The Broken Spell. Cultural and Anthropological History of Preindustrial Europe (New Brunswick, 1991), p. 285.

4 P. Johnson, "Historical Readings of Old Age and Ageing", p. 7.

5 These archipelagos were under British imperial control throughout the period framing this study: the Ionian islands were held as a Protectorate from 1815 up till 1864, and Malta, having been occupied in 1800, was made a Crown Colony in 1813. The latter came under direct colonial administration, with a governor on the spot, while the Ionian Islands were nominally an 'Independent State', though in reality they were governed on strict colonial lines by a Lord High Commissioner from Corfu. 
Nonetheless, this shortage of officially published evidence and of statistical data is, to an extent, compensated by information contained in a handful of specific mostly unpublished - reports and in the voluminous administrative correspondence deposited in separate archives, but also by a large body of literature written by officials, medics, travellers and Protestant missionaries, most of whom were British colonial men stationed on these islands. Paying particular attention to the colonialist preconceptions pervading most of these narratives - especially when it comes to their interpretation of the social manners, roles and lifestyles of the Ionian and Maltese "native elderly", as much as of the other poor of their 'subject' populations - their colonial ethnographic accounts provide revealing details, if principally on the use of charities and relief institutions by the aged.

By locating disadvantaged old men and women at the centre of analysis, this research article seeks to gain a better insight into the complex of routine practices formal, semi-formal or illegal - which these people engaged in, in order to mitigate their high exposure to under-nourishment and disease. This elderly-centred approach also helps to delineate the extent to which self-help activities were actually sufficient for these elderly to survive on a daily basis and particularly during longterm crises. Then, of course, as the main arguments of this study unfold, a series of correlated questions will emerge: What situational tactics were employed by the elderly poor to procure specific resources from communal welfare providers, state institutions and relief agencies? Did the different types of resources offered by separate voluntary organisations and state relief institutions complement or supplement each other? Therefore, does the thesis adhered to by various scholars, and clearly presented by Angela Groppi, that "cyclical oscillations in which the state, families, and charitable institutions redistribute the tasks of caring" for the elderly, ${ }^{6}$ hold for the elderly in these island environments during the period under study? Answers to these inquiries can be found in the intricate relationships, and bargaining abilities, which the elderly poor developed with their household, neighbourhood, community social bodies and with the various formal institutions for a wider range of resources on offer. For this reason, the notion of social negotiation, drawn from a critical tradition in the social sciences, ${ }^{7}$ is employed here to assist the analysis of the habitual bargaining, give-and-take relations, going on between the aging poor and the just mentioned informal, intermediate and formal social nets and institutions operating in the Ionian islands and Malta, in times of normality, and more remarkably still during collective calamities.

6 Angela Groppi, 'Old People and the Flow of Resources Between Generations in Papal Rome, Sixteenth to Nineteenth Centuries', in Ottoway, Botelho and Kittredge, eds., Power and Poverty, p. 89.

7 Peter Burke, History and Social Theory (N. York, 1996), pp. 86-87; Joseph V Femia, Gramsci's Political Thought (Oxford, 1981), p. 42. 


\section{Self-Help, Reciprocal Assistance and the Pooling of Resources}

In contrast to the wealthy, whose possessions, capital and power allowed them to be in a better position to secure a better-off old age, ${ }^{8}$ the aging poor strove to procure their daily sustenance and care themselves whilst capable of doing so. It was habitual for them to remain active participants in their household's affairs and to draw on a common pool of resources. As functional members of the household they were actively engaged in a shared subsistence economy which involved the common use of utensils, tools and provisions, and usually included a particular division of labour. This involved the common use of utensils, tools and provisions and usually included the keeping of "rabbits and fowls" at home, both for consumption and to "bring up for sale, and pay rent with the produce". ' On a more particular level, the elderly also made use of their own belongings, to put their minds at rest regarding the availability of basic necessities and care in the household sphere during longterm illness and frail old age.

Within the peasant households, one principal asset which grounded the old folks' authority and their claim to respect was the men's hold over property, the house and the parcels of terrain which they cultivated, and the aging women's influence on domestic affairs in extended family networks. Similarly within both the Maltese and the Ionian peasantry, it was usual for newly married couples to take up home with one or other of their old folk: a custom which often resulted in "the paternal mansion [being] subdivided into a number of separate dwellings". ${ }^{10}$ Alternatively, newly-weds found a place in very close proximity. This spatial propinquity grounded the extended family network and the associated pooling of resources and reciprocal assistance. In this kind of domestic setting, women played a pivotal role. Their marriages arranged by heads of families, daughters were provided with dowries which included house furniture and utensils, dress and body ornaments. ${ }^{11}$ Consequently, daughters and daughters-in-law were expected to care for their husband's elderly parents, as much as for their own elderly, within the domestic space of the

$8 \quad$ Pelling and Smith, p. 12.

9 'Report of the Committee on the Relief of Distress - 13 December 1824', in Hastings to Bathurst, 3 March 1825, Colonial Office [hereafter CO.] 158/41, Public Record Office, London [hereafter PRO.L.].

10 William A. Goodison, Topographical and Historical Essay upon the Islands of Corfu, Leucadia, and Zante (London, 1822), pp. 223-224; Cf. also Tetius T.C. Kendrick, The Ionian Islands. Manners and Customs (London, 1822), p. 224.

11 Kendrick, p. 15; Viscount Kirkwall, Four Years on the Ionian Islands, their Political and Social Conditions with a History of the British Protectorate (London, 1864), vol.ii, pp. 143-144. 
home. ${ }^{12}$ Thus, familial reciprocal relations and the reputation of the household were both sustained at high level, the latter being greatly dependent on the visible caring of the old.

Certainly, the centrality of the elderly in this system of domestic solidarity based on reciprocal assistance of the family members, ${ }^{13}$ and the accompanying respect they expected, helped to secure for them the needed care particularly when they were unable to help themselves and during the last stages of their life. Even British colonial officials and Protestant missionaries who were frequently severe critics of their Ionian and Maltese 'subjects', would observe that in these islands the elderly who were ailing and unable to work were usually "not abandoned by their children and grand children [even when] these can do nothing for their relief."

Although domestic solidarity towards the old was an ordinary affair in the Ionian and Maltese households, some variations can certainly be observed in the attitudes towards social and health care practices between rural and urban households. But in order to understand this difference it is necessary to provide a brief explanation of the different rural-urban landscapes which structured these household's material conditions of poverty. During the British Protectorate, the Ionian islands' economy remained fundamentally agrarian and characterised by the cultivation and export of currants and olives. This trade was directly dependent on the shifts in demand from external, markedly British, markets. ${ }^{15}$ The sharecropping system, and the conditions upon which field tenancy was held on these islands - the colono arrangement in which the peasant paid a pre-agreed portion of the produce to the signori - kept most of the rural households directly subjugated to their landowners. ${ }^{16}$ Identically to their Maltese counterparts, most of the Ionian peasantry held tenancy over small parcels of land on which all the family members worked, including those elderly who were "less worn out". ${ }^{17}$ When it came to aging women, besides their contribution as farm hands, they also took care of the goat and sheep herds. Together with the younger females they also occupied themselves in other manual activities, thus

12 See John Davy, Notes and Observations on the Ionian Islands and Malta with some remarks on Constantinople (London, 1822), vol. ii, pp .141-142; Goodison, p. 186; Kendrick, p. 14.

13 For the domestic organisation of the household in Greek society during the nineteenth century see Paul Sant Cassia and Constantina Bada, The Making of the Modern Greek Family: Marriage and Exchange in nineteenth century Athens (Cambridge, 1992), pp. 1-45.

14 W. Bullock Webster, English Governors and Foreign Grumblers in Malta in 1864 (London-Malta, 1864), p. 58; Reports of the Commissioners Appointed to Inquire into the Affairs of the Island of Malta and of Correspondence Thereupon (London, 1838), p. 9.

15 David Hannell, 'The Ionian Islands under the British Protectorate. Social and Economic Problems', Journal of Modern Greek Studies, 7 (1989), pp. 105-132.

16 Adam (Corfu ) to Bathurst, 13 July 1824, CO.136/22, PRO.L; Michael Pratt, Britain's Greek Empire. Reflections on the History of the Ionian Islands from the fall of Byzantium (London, 1978), p. 115.

17 Reports of the Commissioners, pp. xvii, 8-12, 140. 
supplementing the family's income. ${ }^{18}$ Indeed, colonial officials and travellers observed that, for instance on Corfu, "nearly all, young and old [women], carried the never-ceasing distaff and spindle, with which they are forever at work [while] tending their goats and sheep". ${ }^{19}$ Peasant women were also seen knitting and embroidering, ${ }^{20}$ carrying "wood and water .... at the olive mill and perform, in fact, every laborious office", while looking after their grandchildren. ${ }^{21}$

Living precariously on economies of subsistence, these insular rural communities were characterised by a continuous migration movement. During the sowing and harvest periods Southern Ionians, mostly males, crossed the sea to work as labourers in the Morea, the Albanian littoral and other islands in the vicinity. For their work they were usually paid in kind..$^{22}$ Apart from these seasonal flows, other thousands of Ionians and Maltese gravitated towards the Levantine and North African territories to work as labourers, artisans or petty traders and thus supported their family, and aging parents, by regularly sending back remittances. ${ }^{23}$ Emigration was by and large left to the younger male members of the household: ${ }^{24}$ those feeling "too old" to travel were left at home with the responsibility to help and protect the family and to manage domestic affairs. They kept the farm going and, when need arose, secured better terms of tenancy and negotiated new deals and alliances with landowners and other family clans through deep-rooted networks in which loyalty and respect played a pivotal part. ${ }^{25}$

This kind of multifaceted and active involvement of the aged in household matters, accompanied by their share of daily labour, was essential to the creation of a receptive and caring atmosphere that would ensure that the necessary support would be forthcoming during illness and infirmity. For this purpose, within the intimate domestic space, the elderly would consolidate affective relations with specific individual members through generous gifts, mainly of personal effects which

18 D. T. Anstead, The Ionian Islands in the Year 1863 (London, 1863), p. 318; Davy, p. 45; Reports of the Commissioners, p. 9.

19 Dr. Corrigan, Ten Days in Athens with Notes by the Way (London, 1862), p. 23.

20 Davy, pp. 141-142.

21 Anstead, p. 37; Goodison, p. 210; John Hennen, Sketches of the Medical Topography of the Mediterranean. Comprising an Account of Gibraltar, the Ionian Islands and Malta (London, 1830), p. 145; Kirkwall, pp. 142-143, 288; On child caring as a daily occupation for the elderly in the villages see Fatima Mansur, Bodrum. A Town in the Aegean (London, 1972), p. 147.

22 H. Holland, Travels in the Ionian Isles, Albania, Thessaly, Macedonia Erc. during the years 1812 and 1813 (London, 1815), p. 22; Kendrick, p. 65; W. M. Leake, Travels in Northern Greece (London, 1835),vol. iv, p. 72.

23 Bullock Webster, p. 58; Pratt, p. 144.

24 Ionian Islands Blue Books [hereafter IIBB.], 1863.

25 Cf. George Bowen, Ithaca in 1850 (London, 1851), p. 17; C. P. De Bosset, Parga and the Ionian Islands: Comprehending a refutation of the various Mis-Statements on the Subjects (London, 1822), p. 31; C. Willis Dixon, The Colonial Administration of Sir Thomas Maitland (London, 1968), pp. 204-405. 
included body ornaments ${ }^{26}$ (worn both for aesthetic reasons and as security for pawning purposes), gained during their lifetime, as dowry or as inheritance. Besides the parcels of land, which the family cultivated were a most important asset in the hands of the elderly, mainly the males, and were deployed to ensure the provision of caring and treatment within the household. With the prevailing system of inheritance, dictated by the tradition of the "male line of descent", land holdings were divided among the males of the family. Due to the internal family arrangements which it sustained, this customary mode of property transmission remained nearly intact on all of these islands, in spite of the fact that the British authorities on Corfu sought to abolish it. ${ }^{27}$

Although the British maritime domains under discussion remained predominantly rural, the colonising presence was nevertheless felt, in different degrees, in the core harbour areas of the main islands of Malta and Corfu and to a much lesser extent in Argostoli (Cephalonia) and Zante Town. ${ }^{28}$ Narrowing down our analysis to the urban districts of the two principal islands, it still remains evident that the households of the urban poor played an important role in the care of their aged. Having said this, the elderly living in these urban districts were characterised by their inclination to make use of the more immediately available relief institutions and services, particularly the asylums, as key elements in their daily survival strategies. This could be observed more remarkably with the passing of time, within the social parameters of the Valletta-Cottonera Harbour district in Malta, followed by Corfu Town. As from 1841, especially from the time of the Crimean War (185456) onwards, Malta was built up as the key strategic naval-military and coal-bunkering station on the British maritime route to the Levant and to India. It was this enhanced geo-strategic position that transformed this island's central harbour district into a strategic imperial base which, in turn, attracted an increasing number of people to work in its naval and trade establishments. Inside this densely populated urban district, working class households came, at least formally, to depend on the wage earned by a male breadwinner during his most productive years. In this way, working class households became ever more strongly characterised by a strict division of labour based on gender and age. ${ }^{29}$ The age factor meant that as the end of their productive years approached, male workers who were still in employment became liable to summary dismissal from one day to the next. A small number of

26 Cf. Hennen, p. 178; Martin R. Montgomery, History of the British Possessions in the Mediterranean (London, 1837), p. 342.

27 Napier (Cephalonia) to Rusdell, 24 June 1828, CO.136/1309-647, PRO.L.; Davy, pp. $318-320$.

28 Douglas to Normanby, 25 Apr. 1839, in enclosure Douglas to Glenelg, 21 June 1838, CO.136/93, PRO.L.; Kirkwall, p. 42.

29 John Chircop, 'The British Imperial Network in the Mediterranean 1800-1870. A Study of Regional Fragmentation and Imperial Integration', Unpublished Ph.D. thesis, University of Essex, 1997, p. 90. 
those who claimed a long period of permanent service with such establishments as the British Commissariat were granted a very modest annual sum on retirement. This could happen at any point after sixty years, on being declared old and infirm or "unhealthy" - usually suffering from rheumatism, apoplexy, dropsy or a "disordered intellect". "Unavoidably then, most of the wage-dependent aging men had to resort to a combination of self-help occupations of every sort, complemented by an extensive use of the state institutions and poor relief services available in their vicinity, when out of work.

For aging males who were unemployed in the urban districts, and who did not suffer from disabilities, there was only a restricted choice of other paid occupations available. In Malta, one option was recruitment into the poorly-paid police force which, until the mid-1830s, was reportedly made up mainly of "aged men" ${ }^{31}$ Others who were progressively over forty years of age, "still going strong", and who had already served in the army, could also enlist in the Veterans' Battalion. At first constituted as a three hundred men corps, recruited "from amongst the oldest and most steady for this purpose", the Veterans were employed to assist the civil government and the police in the keeping of social order and public sanitation..$^{32}$ Enlistment provided a monetary income, essential provisions (food and clothing) through the "army's bounty", and an option to reside in the barracks, besides a degree of formal respectability which came with the wearing of a uniform. Each veteran who was engaged in a three or five year contract was provided with 12 dollars, out of which the following provisions were supplied: " 1 knapsack; 1 pair trousers; 2 shirts; 1 pair of shoes; pair gairters; brushes, forage cap, great coat cap strap, comb, sponge etc.: clothing and appointments as ascribed by H.M.'s regulations". ${ }^{33}$

Army supplies, medical treatment and the possibility of shelter, made the Veterans very popular with the elderly poor and their families. It was for this reason that the battalion was retained even after the restructuring of the military establishments. Then, by 1850, veterans were enlisted in the Royal Fencibles Pensioners on a seven year contract open to those over forty years old and who had already served in the army. ${ }^{34}$ This recruitment was primarily intended to encourage "young natives" from 15 to 25 years (for the Royal Fencibles Artillery) or from 18-35 years (for the Royal Malta Regiment), and who had the required 5 feet 3/4 inches in height, to involve themselves in the Army: "where they would hope for such an

30 'Estimates of Amount required for Retired Pay, Compensation etc 1845-1846', in British Parliamentary Papers [hereafter BPP.], 1845, vol. XXIX, 104; 'Compensation and Superanuation Allowances for the Commissariat - 1850', in BPP., vol. XXIV, 119.

31 Reports of the Commissioners, p. 42.

32 A. Chesney, Historical Record of the Maltese Corps of the British Army (London, 1897), pp. $35,37$.

33 Ibid, pp. 48, 95.

34 More O'Ferrall (Malta) to Earl Grey, 5 Dec. 1850, disp. no. 133 in "Report Accompanying the Blue Book for 1849", in BPP., 1852-1853, vol. LXII. 
asylum in their old age". ${ }^{35}$ The Pensioners performed duties related to policing and state ceremonials,${ }^{36}$ being called out for military drills one day each month on payment, up till 1861 when upon expiration of their contract, this corps was dismantled. The public protests and the petitions presented to the authorities, when the disbandment of this force became known, attest to the part played by these army corps in the all-round survival strategies of the poor: "the proposed disbandment, besides casting many families into distress, is sensibly felt by all the population [... as the corps] provided food for practically 3,000 souls" ${ }^{37}$ This occurred in Malta, with no similar arrangement for veterans being found on the Ionian islands. Here, even the Island Militia, organised during the first decade of the British protectorate, which included all males "from 16 to 60, capable of bearing arms", had been discontinued ${ }^{38}$ leading High Commissioner Sir Henry Ward to voice concern that for the locals there was "no army or navy to go into".

Besides those fit and wanting to join the army in Malta, cases recorded from the main urban districts in all of the islands under discussion show the elderly poor active in makeshift occupations. Old men frequenting wine taverns and coffee shops, or in public squares, were observed lending a hand to passers by and offering their services to travellers as guides, as porters, or as carriage drivers upon payment of money or in kind..$^{40}$ Aged women were witnessed as domestics, but also offering rooms in their homes for lodging to foreigners, and frequently met as hawkers, petty-brokers, healers and midwives. ${ }^{41}$ Suchlike activities were usually blended with an array of semi-formal or illegal activities including practicing of witchcraft, pawning and purchasing food on credit from shopkeepers, begging and all sorts of thievery. ${ }^{42}$ Most of these informal practices were observed in the central towns of the main islands, as in Corfu Town and Argostoli, or the area known as Nix Mangiari in Valletta where crowds of elderly and children gathered to beg. ${ }^{43}$ Yet it is only from the earliest published official census of Malta in 1851, that one can get the first rare glimpse of the sex distribution of the officially "known elderly mendi-

35 Chesney, Historical Records, pp. 47, 129.

36 A.Chesney, 'The Maltese Corps of the British Army', in A. MacMillan, ed., Malta and Gibraltar Illustrated (London, 1915), pp. 289-291.

37 Ibid, pp. 103-104.

38 Martin R. Montgomery, History of the British Empire, Comprising the areas, agriculture, commerce of each colony: Possessions in Europe, (London, 1843), vol.iv, pp. 398-399; Henry JervisWhite Jervis, History of Corfu and of the Republic of the Ionian Islands (London, 1852), pp. 320321.

39 Quoted in Hannell, p.109.

40 Anstead, p. 318; Hennen, pp. 188-189, 408; W. Kimber, Edward Lear in Greece. Journals of a Landscape Painter in Greece and Albania (London, 1965), p. 75.

41 Davy, pp. 141-142; Goodison, p. 193.

42 'Report of the Committee - 13 Dec. 1824', in Hastings to Bathurst, 3 March 1825, CO.158/41, PRO.L.

43 Davy, pp. 120-121; Hennen, pp. 188-189; Reports of the Commissioners, p. 9. 
cants", in the 66+ age bracket, active in this harbour urban district. It transpires that old males, in this age range, formed the largest proportion of this officially counted localised sample of beggars: with 125 males against 70 females. ${ }^{44}$ Aging women are shown to be less inclined to go out begging or, in any case, to declare this to official enumerators.

\section{Resourceful Elderly and the Care of the Body and the Mind}

Prolonged economic crises and cyclical unemployment, which distinguished the economies of these British-held island territories ${ }^{45}$ hit hardest in the colonial port urban centres of Malta and Corfu, where, for many of the elderly, poverty was transformed into outright destitution. Together with the rest of the unemployed, the aged crowded the streets, "some in a state of absolute nudity, with all the others in rags [...] old men scarcely able to work; women the picture of famine", ${ }^{46}$ struggling to maintain themselves by "gather[ing] herbs and dung off the roads which they sell". ${ }^{47}$ Besides queuing at charity soup kitchens, scavenging and pilfering from public and private property, old males and females made the most of communal resources found in the towns, such as water fountains and wells, and used open spaces at the margins for snaring and trapping. Common land, stretches of public wasteland, accessible woods, and mountain forests as in Cephalonia, or the seashore common to all islands, were primarily exploited to increase nutritional intake, but also for medical purposes, from the natural resources - spring water, wild vegetation, plants, herbs, wild game, seafood, weeds and fish - found therein. ${ }^{48}$

On these occasions, the local village elderly were usually fetched for advice on the customary rights and obligations regulating the utilisation of the commons, which were normally left for grazing. Knowledgeable of the specific locations, and of the most sensible times and ways of foraging and collecting wild plants and raw materials, the local elderly were indispensable to help the urban poor locate, properly extract and utilise such natural resources as food, medicine and, when it came to dry wood and thistle, for practical survival purposes. When it came to consumption, the indiscriminate foraging and haphazard ingestion of wild vegetation, herbs and roots, including those which were "indigestible [and] fit only for cattle" were

44 Census of the Islands of Malta, 1861, p. 146. This gender disparity in the recorded 'beggar population' continued, at least, to the last decade of the nineteenth century (Cf. Census of the Islands of Malta, 1891, Table XXIX).

45 Reports of the Commissioners, p. 9; Chircop, pp. 161-162.

46 A. Malcolm, Letters of an Invalid from Italy and Malta (London, 1897), p. 275.

47 Reports of the Commissioners, pp. 8-9.

48 Charles J. Napier, Memoir on the Roads of Cephalonia (London, 1825), p. 9; Kirkwall, p. 142 . 
known to cause inexperienced town people a variety of illnesses. ${ }^{49}$ Consonant with their roles as depositors of indigenous wisdom, and as upholders of customary law, several village elders, both men and women, were regularly fetched for their curing practices and for advice on bodily care and herbal medication. ${ }^{50}$

Knowledge on the potential for nourishment and healing contained in natural resources constituted only a portion of the indigenous knowledge which the elderly transmitted verbally, and through habitual practice, within the family and the neighbourhood. Old men and women also passed on to their children and grandchildren fundamental notions, values and skills which were believed to be indispensable for survival in a poverty ridden environment. This they did through story telling, lamentations, anecdotes and songs, in which wise old persons like themselves were central protagonists and heroes. ${ }^{51}$ It was through these verbal arts that values of communal solidarity and mutual assistance, and related notions of prudence, hoarding ('saving for a rainy day') and recycling were transmitted to the young. Individual cleverness and shrewdness, which were highlighted as negative Orientalist features of the Greek Ionians, and also of the Maltese, by many British colonial officials and travellers ${ }^{52}$ (and lately explored by modern anthropologists such as Michael Herszfeld as elements in a strategy to defend the Greek household's reputation), ${ }^{53}$ were actually indispensable attributes that enabled the poor to manipulate, and effectively bargain, relief for themselves and their household. Being such, these were positively reinforced by the elderly within the family sphere.

Embodying indigenous wisdom, traditional values and shared memories of the community, several elderly were looked upon as organic representatives of the general interests. This should not be taken to mean that all the elderly were looked upon with unwavering respect by all, as contemporary recorded cases of usurpation and public disrespect by the young confirm. ${ }^{54}$ Talented older persons did hold important positions in local social bodies and mainly in confraternities. Deeply entrenched in the villages and towns, these semi-religious associations played an

49 Reports of the Commissioners, pp. 9-11.

50 On indigenous medicine and healing practices in the Ionian Islands and the Maltese archipelago see. Agius de Soldanis, Ghaudex bil-Grajja tieghu (Malta, 1836), pp. 45-47, 144-145; Hennen, pp. xxxiii, 166, 193-197, 278, 293-297, 329-330; Montgomery, History of the Colonies, pp. 341, 344.

51 G. F. Angas, A Ramble in Malta and Sicily in the Autumn of 1841 (London, 1842), p.34; G.F. Badger, Description of Malta and Gozo (Malta, 1838), p. 97; Charles J. Napier, The Colonies; treating of their values generally and of the Ionian Islands in particular (London, 1833), p. 264; A. A. Pallis, Greek Miscellany. A Collection on Medieval and Modern Greece (Athens, 1964), p. 168.

52 Anstead, p. 450; Hennen, p. 371.

53 Michael Herzfeld, The Poetics of Manhood: Contest and Identity in a Cretan Mountain Village (Princeton, 1985), p. 198.

54 Goodison, p. 224; Kendrick, p. 13. 
important role in helping to organise social assistance and to help individuals mitigate misfortune, especially during fragile old age. Although these social bodies aided the general community of the poor through alms, food and clothes, normally on specific days of the liturgical calendar, their primary concern lay with the welfare of their own members: the majority of confratelli and the small number of female consorelle. When members faced protracted illness or infirmity, the confraternity provided the services of a doctor, nursing care, medicine and foodstuffs, but also a measure of emotional support. To be sure, for such a benefit system to be economically sustainable, membership had to start early in life, with the annual payment increasing according to the age of the individual. As a rule, one could not become a member in old age and this meant that each associate would normally provide longterm contributions, both in financial terms and as service to the collective body, before one's own time to receive assistance arrived. ${ }^{55}$ Certainly, this makes evident the fact that in their majority, confraternity members were labouring poor and artisans and did not come from destitute households.

With paid membership in a confraternity, an individual did not only secure a certain measure of assistance during eventual illness, but also guaranteed spiritual support, solace on the death bed and interment of their corpse in a consecrated grave. ${ }^{56}$ A paid-up confratello would expect post-mortem prayers and the celebration of mass for suffrage of his own soul, when "in Purgatory", after death. He also expected his widowed wife to be helped out, at least for a short period of time, with money, cereals and clothes. Meanwhile being one of the confreres, he was expected to accompany the priest carrying the viaticum (the last communion) and to be present when extreme unction was performed to a dying 'brother'. Afterwards all brothers were likely to help in the preparations for the funeral ritual and for burial in the confraternity's chapel $^{57}$ as was done in Corfu, or in the assigned grave within the village church crypt ${ }^{58}$ as in Malta. Reassurance of a decent funeral and entombment in an identifiable grave was considered by most of the common people as of utmost importance, as this was associated with a person's respectful social and moral status. ${ }^{59}$ The paramount significance given to the burial issue by the parishioners was demonstrated when the British authorities prohibited the custom of interment

55 Joseph Galea, Il-Konfraternita tal-Bumbardiera fil-Knisja ta' Santa Barbara (Malta, 1988), pp. 45-48.

56 Cf. Christopher F. Black, Italian Confraternities in the Sixteenth Century (Cambridge, 1989), p. 231; L.B. Lenoci, 'Il Culto del SS. Sacramento in due statuti confraternali meridionali', in Archivio Storico Pugliese, 39 (1986), pp. 161-183.

57 Nondas Stamatopoulos, Old Corfu - History and Culture (Corfu, 1993), pp. 39, 40, $213,223$.

58 Hennen, pp. 85, 188, 466; Montgomery, History of the British Possessions, pp. 183, 101.

59 Elena Brambilla, 'The Definitions of Citizenship and the Sacramental System of Churches' in A. Cimdina, ed., Religion and Political Change in Europe: Past and Present (Pisa, 2000), pp. 77-78. 
of bodies within the boundaries of Greek Orthodox and Catholic churches by orders issued, for sanitary reasons, in all their Mediterranean possessions. ${ }^{60}$ According to these sanitary regulations, interment of corpses was to be carried out only in government approved extra-mural cemeteries and this provoked lingering dissent and varying forms of opposition throughout these islands. ${ }^{61}$

In the Greek Orthodox and Catholic cultures which were dominant in Ionian and Maltese social terrains respectively, the process of dying was in itself an important household and community affair. As Dr John Hennen, a contemporary medic and author stationed on these islands, observed: "A Santa Mauriot [an inhabitant of the island of Santa Maura] always dies amid companions and visitors, however neglected he might be during life, or little thought of after death". ${ }^{2}$ And so did the poor inhabitants of all the other islands under discussion. Being accompanied by confraternity brothers or not, dying was a social affair, encompassing the family, neighbours and friends - all of whom were expected to help out in the funeral ceremony and the burial of the corpse. ${ }^{63}$ Thus, the fear of dying alone constituted one other reason for the elderly sick to dread the civil hospital and the asylum, as will be discussed below, and must have also further motivated those who could afford it to seek membership in a confraternity.

\section{Negotiating Formal Relief and Expecting a Place in an Asylum 'by Right'}

The extensive system of state public outdoor relief and charitable institutions, sanctioned by the local Churches and the confraternities, constituted a mainstay of British colonial power in the Ionian Protectorate and Malta. Certainly, maintaining a network of charitable establishments and relief services for the elderly poor formed part of a wider low-cost strategy to extend social control and to foster consent for the colonial state and the social order. ${ }^{64}$ This was made evident by the Crown Advocate of Malta who, in 1861, declared that the colonial administration had an intimate interest in assisting, through alms, relief and medical care "all of those afflicted with old age and disease". ${ }^{65}$ In this way it was anticipated that the

60 Hennen, p. 187; Montgomery, History of the British Possessions, pp. 183, 101.

61 W. E. Gilpen (Corfu), 6 Oct. 1836, 'Circular to the Respective Residents'['on the subject of forming a cemetry for individuals of the dominant religion instead of continuing the injurious practice of interning bodies in the Churches'], CO.136/1137, PRO.L.; Galea, p. 49.

62 Hennen, p. 375.

63 Cf. Goodison, p. 225.

64 Adams (Corfu) to Douglas, 18 Jan. 1824, CO.136/22, PRO.L.; Letter to H. E. Duke of Newcastle by Four Elected Members of the Council of Government (Malta, 1864), pp. 22-23.

65 Library Mss., 16 Jan 1861, Rabat National Archives of Malta [hereafter RNA.M]. 
state could prevent the aging poor and their families from resorting to undesirable activities, such as vagabonding, trespassing, begging and theft, which were all classified as crimes. ${ }^{66}$ And this power strategy was articulated by a colonial rhetoric which coupled the "native elderly" poor with orphan children and the foundlings as being in constant need of the government's paternal benevolence, caring and nurturing. ${ }^{67}$ Indeed, although attempting, now and again, to reform - with some doses of Benthamite Utilitarianism - these old charitable systems inherited from the previous regimes of the Venetians and the Order of the Knights of St. John, that had ruled Corfu and Malta respectively, the British authorities, aware of the social and political implications any such alterations might have for the colonial state of things, continued to implement a paternalist policy towards the poor throughout the period under discussion.

What needs to be stressed at this juncture is that the cost of maintaining such an extensive government charitable system for the poor, and the old in particular, was mainly defrayed from local revenue, though this was supplemented by constantly inadequate private subscriptions and bequests. In the Ionian islands and Malta the annual government expenditure on the upkeep of the charity establishments, including the asylums for the aged poor, were funded from taxation, principally from a tax on grain which weighed heavily on the poorer classes. ${ }^{68}$ This confirms the soundness of the recirculatory theory of state charity, which suggests that the poor were ultimately paying for their own relief through their life-long tax contributions. When considered in conjunction with the paternalist mentality of the people as moulded by its experience of the ancient regime, the actual experience of contributing directly for their own relief through taxation helps to explain the claims, and expectations, of the poor for state charitable relief "as by right". ${ }^{69}$ It is in this context that one starts appreciating this extensive public charity sphere, maintained by British colonial governance, as a major cultural-hegemonic terrain in which the common people were constantly able to negotiate outdoor relief and social assistance. ${ }^{70}$ In their face-to-face modes of bargaining, or through official petitioning, the elderly with the other groups of the poor, employed, or rather manipulated, the same official discourse used by the state. They pleaded to their administrators' "paternal hand of authority and benevolence" when applying for

66 'Bandi della Corte di Malta' (24 Aug.1812), RNA.M; Davy, pp. 118, 303; Montgomery, History of the Colonies, pp. 220-223.

67 Adam to Douglas, 18 Jan. 1824, CO.136/12, PRO.L.; Anstead, p. 15; Kirkwall, p. 37.

68 IIBB.,1847; Maitland to Bathurst, 24 Oct. 1814, CO.159/39, PRO.L.; Mrs. C. Lushington, Narrative of a Journey from Calcutta to Europe in the Years 1827 and 1829 (London, 1829), p. 205.

69 Paul Cassar, Medical History of Malta (Malta, 1964), pp. 102-126; Hankey to Horton, 24 July 1825, CO.158/42, PRO.L.

70 Hennen, pp. 485; Cf. also P.P. Castagna, Lis-Storia ta Malta bil Gzejer Tahha (Malta, 1888), vol. i, p. 441; Malta Government Gazette [hereafter MGG.], 16 April 1817. 
relief and, more specifically, when requesting admittance in the Ospizio. The language of distress employed in their petitions tacitly cautioned that without poor relief most of them would resort to "begging and other disorderly occupations", thus making the authorities "fear that idle if not vicious habits will quietly become generated amongst them", ${ }^{71}$ possibly provoking social disturbances.

In the urban centres, the elderly were at the foreground of the numerous poor who used formal charitable institutions and outdoor relief as an essential part of their strategy for survival. A large portion of the poor faced harsh destitution when getting old. These people included those who had depended all their life on precarious work activities, and most of whom were normally paid in kind, and thus could not, "however frugally and industrially they may pass their youth, put by any provision for old age". ${ }^{72}$ Most of these attempted to use all relief services available in their immediate surroundings. Besides the parish-based services of the proto-medico, or doctor of the poor, and the public dispensaries in the main towns, ${ }^{73}$ the aging poor employed the state institutions of the Ospizio and the Monte di Pieta. Having a long established history, starting as from the seventeenth century on Corfu , Zante, Cephalonia, Ithaca and Malta, ${ }^{74}$ the Monti were state-owned pawnbrokers consolidated as principal social safety valves to afford "pecuniary relief to the distressed [...] thereby preventing them from having recourse to usurious contacts" by the British authorities. ${ }^{75}$ Subsequently, private pawning was officially prohibited on those islands of the Protectorate where a Monte di Pieta ' was operating. ${ }^{76}$ By pawning their commodities and personal belongings (including clothes, silk/linen, woollen articles and body ornaments) in the Monti di Pieta', the elderly could sustain themselves, and their households, at least temporarily, during times of adversity. Records show that most of them generally retrieved their objects when

71 'Report of the Committee - 13 Dec. 1824', in Hastings to Earl of Bathurst, 3 Mar. 1825, CO.158/41, PRO.L.; An appeal on behalf of the Widows, Orphans among the Corfiotes now suffering, (Corfu, 1836); Rapporto della Societa ' Caritatevole di Cefalonia (Corfu, 1843).

72 Reports of the Commissioners, p. 9.

73 Hennen, p.328; Montgomery, History of the British Possessions, p. 247.

74 F. Lunzi, Dalla Conditione politica delle Isole Ionie sotto il Dominio Veneto (Venezia, 1858: fasc. repr. 1969), pp. 243-248; R. Micallef, Origins and Progress of the Government Charitable Institutions in Malta and Gozo (Malta, 1901), p.19; 'Inventario del Santo Monte di Pieta' in Corfu de Gennaio 1842 a tutto Dicembre 1846', 11/43, State Archives Corfu, Greece [hereafter SAC.G.].

75 Hennen, p.189; Kirkwall, p. 37.

76 Seconda Sessione Del Primo Parlamento degli Stati Uniti delle Isole Jonie tenuta in virtu' della Constituzione del 1817. No. XI. Atto del Parlamento che proibisce ai particolari in tutte le Isole degli Stati Uniti delle Isole Jonie, ove esistessero Monti di Pieta', di dar o ricever denari con pegno (Corfu, 1819). 
able to do so, ${ }^{77}$ and reutilised them, time and again, for the same or for other survival purposes.

The combined use of these various charities formed part of a strategy employed by the elderly in which the Ospizio or Asylums for the Aged and the Infirm, played a central role. These institutions were located within the capital towns of the main islands, and even though leaving much to be desired by the official standards of the time, ${ }^{78}$ were nonetheless sought by the old in need, at least for periodical stays: "or till that can be done, to be allowed a monthly stipend, as out door partakes of the funds of that establishment". ${ }^{79}$ During hard times, the transfer of an elderly person, and usually the male, to the asylum, formed part of a shared strategy practiced by old couples, and their families, in order to "free the confined habitation of a large family [and provide] more room for working something profitable", giving them a temporary respite.

One other trait can also be discerned in the use of the asylum by the aged poor. Many moved in and out of these institutions as part of a flexible strategy to secure daily dietary requirements, shelter and medical assistance according to the season, their household subsistence situation and the general economic circumstances prevailing at specific times. Evidently, during economically stable periods, and during summer, many of the elderly could do without the resources found in this institution to the point of finding it opportune to bargain their place of stay. This is most evidently seen in the case of the central Floriana asylum in Malta. Confronted with the problem of limited space and the associated high-risk of epidemic outbreaks, the authorities of this asylum introduced the practice of discharging as many inmates as possible during the summer months. Those elderly inmates who were willing to return to their households, relatives or friends, were given an allowance of three pence each day in lieu of rations. ${ }^{81}$ In the subsequent years, as the warm months approached, the inmates would start making it evermore difficult to leave the asylum, pressing the respective authorities to pay more. Money continued to be disbursed, even though the authorities knew well enough that this did not prevent the elderly from begging and that the payment was going "in the pockets" of their relatives. ${ }^{82}$ In contrast, this asylum was usually packed throughout the winter, dur-

77 Cassiere del Monte' di Pieta' (Corfu) to Collona, 9 April 1846; "Inventario del Santo Monte di Pieta 'di Corfu. Da Gennaio 1842 a tutto Dicembre 1846", 11/43, SAC.G; MGG., 4 Oct. 1846.

78 Regulations of the Charitable Institutions in Malta and Gozo (Malta, 1858), pp. 45-46; Davy, p. 109.

79 'Report of the Committee - 13 Dec. 1824', in Hastings to Earl of Bathurst, 3 Mar.1825, CO.158/41, PRO.L.

80 Reports of the Commissioners, pp. 8-9; Hastings (Malta) to Earl Bathurst, 20 April 1825, CO.158/41, PRO.L.

81 Cassar, p. 379.

82 Ibid., pp. 378-379. 
ing general crises and massive unemployment. During the cold months, it was usually more secure to stay in the Ospizio, with less risk of contracting summer-related diseases, where basic necessities and medical care were immediately available. Effectively, one meal a day for each of the aged in the Floriana asylum included: "bread (20 oz.), paste for soup ( 4 oz.), meat or salt fish, cheese ( 2 oz.), 2 eggs, olives, 1 piece of fruit, wine ( $1 / 2$ pint for men and $1 / 4$ pint for women), vegetables for soup [...]. broth and other extras allowed to those sick inmates. ${ }^{, 83}$ On entry, each old person was also provided with: "1 palliase; 1 bolster, 1 blanket, 1 coverlet, 1 set of boards and trestles. 2 sheets and pillow cases [were] allowed to the bedridden and infirm, 1 locker or bedside table and all other necessary utensils. For men -3 shirts; 3 jackets; 3 pairs of trousers; 2 caps; 1 straw hat. For women -3 shifts; 3 jackets; 3 petticoats; 2 kerchiefs" ${ }^{84}$ Both the asylums and the civil hospitals provided an ordinary burial for the destitute elderly who died within their confines.

Even if periodical stays in the asylum was a key element in the combined strategy of survival of the aged, permanent confinement in these same institutions was dreaded by most of the poor not least because of their separation from family and friends. Before the reorganisation of the public charity establishments in Malta and the Ionian islands, which started from the mid-1840s, asylums enclosed paupers, "deranged" and disabled persons, poor spinsters, prostitutes and women prisoners with the aged under one roof. ${ }^{85}$ This state of affairs, added to the restriction of space and overall shabby conditions, helped to spread the perception of the Ospizio as a bleak place and therefore, permanent transfer to these places was usually resisted by the infirm elderly, especially by those coming from the countryside and from the smaller isles. ${ }^{86}$ Evidently, for the aging poor, moving permanently to one of these institutions was associated with the last stage of life, with disability, mental decay, powerlessness and with dying in an impersonal environment. The higher rate of death "incurred among aged paupers" in these charity institutions, and their association with the outbreak of epidemics such as cholera, as much as the believe that the corpses of dead inmates were used for post-mortem examinations, deepened popular fear of dying in these asylums. ${ }^{87}$

83 Storia della Societa' Medica d'Incoraggimento (Malta, 1845), p. 156; Bullock Webster, p. 26.

84 Montgomery, History of the British Possessions, pp. 246-248.

85 Hennen, pp. 196, 483. See also notes on the use of the Ospizio in Corfu, 'da recoverare gli indigenti colorosi' in 1850': 'Commissione Municipale del'igiene Pubblica, Corfu, il 12 Settembre 1850 - copia del processo verbale tenuto alla Commissione Municipale all' Igiene Pubblica, per ogni successivo effetto di legge' (Corfu, 7 Settembre 1850), 11/6, SAC.G.

86 Cassar, pp. 192-193; A. Cremona, L'Ospizzju tal-Furjana u l-Erwieh ta' Wied Ghammieq (Malta, 1959), passim.

87 Cassar, pp. 193-194; Davy, pp. 109, 265; Henry Jervis-White Jervis, p. 236; Micallef, p. 20. 
As part of the above-mentioned state reorganisation of the hospital sector in Malta and Corfu and in the adjoining islands, ${ }^{88}$ the elderly were placed in separate buildings from other sick patients, the mentally ill and from female prisoners. But the policy of separation according to sex within the same institution led to the splitting of aged couples in different sections of the same asylum. ${ }^{89}$ This procedure must have further shaped the elderly couples' decision for only one of them, usually the male, to find a temporary place in this institution. This itself helps to explain why elderly males formed the bulk of those within the 65-90+ years bracket occupying a bed in the central state asylums of Malta and Gozo in 1851-1861, even though females constituted the larger share of the total age range as of the general population. To be sure, males formed the majority of those elderly, within the above age range, counted in all the other civil hospitals all over the islands. In contrast, elderly women in the same age group were, in their large majority, to be found at home. At this point, it is significant to note that the 1851-1861 statistics indicate that those 'aged and infirm' being domestically cared for lived longer that those found in the asylums, and not infrequently living up to the ripe age of 95 and 100 years. $^{90}$

\section{Conclusion}

The general picture which emerges out of this study shows the elderly poor, in both rural and urban contexts, actively engaged in obtaining daily requirements for themselves and, more frequently than previously thought, for their families, for as long as they were physically capable of doing so. While self-help practices, both within and out of the households, consumed most of the daily energy and time of aging men and women, it also becomes evident that these activities were usually not sufficient to secure the provisions, medication and social care they needed during times of unforeseen adversity caused by illness, disability and economic ruin. In response to these distressful conditions of poverty, the aged employed their lifeexperience, customary knowledge, social skills and multivarious practical competences, to bargain for relief and medical care from a combination of household, community and the more formal state charity agents and institutions.

From the specific inquiry over the use of the state charitable institutions and relief by the elderly, two remarkable traits have surfaced. Firstly, that a circular movement, in and out, patterned the use of the asylum by the elderly, and this according to season, individual and household situational requirements, and general

88 Leiton (Corfu) to Earl Grey, 18 April 1846, no. 45, CO.136/124/1846, PRO.L.; W. Reid (Malta) to Duke of Newcastle, 13 April 1853, no. 27, in BPP., 1852-53, vol. LXII.

89 Davy, p. 109.

90 Census of the Islands of Malta 1861, pp. 144-145. 
economic circumstances prevalent at a particular time. Secondly, that when it came to avail themselves of the formal outdoor relief and charitable institutions, elderly couples within their households practiced what is here termed a shared coping strategy, by which one of them, usually the male, occupied a place in the asylum, at least temporarily, and thus providing some respite for the rest of the household. Both these traits illustrate the flexible and adaptive nature of the coping strategies employed by the aging poor, particularly in the urban districts under discussion. Moreover, this goes a step further to explain why, at least according to the more reliable statistics available as from 1851, males formed the largest proportion of inmates in the public asylums, of those petitioning for relief and of those recorded as public 'professional' beggars.

Another contribution made by this study is to prove that on these British-controlled islands, the elderly poor, most particularly those living in the urban districts, showed themselves capable of negotiating with state relief agencies and institutions, especially when it came to procure indispensable provisions, medical treatment and shelter. Besides their individual face-to-face culture of bargaining with these providers, it has also been shown that the old people's claims for relief were expressed in a common language of distress which articulated the collective mentality of the Ionian and Maltese poor of expecting relief from the state "as by right". It has been argued here that this did not only form part of a cultural tradition inculcated in the people by centuries of state paternalism, but was grounded in and reproduced by immediate material factors: primarily the lifelong tax contributions on consumables paid by the poor themselves and which, forming the greater part of state revenue, compensated for all the charitable support they would get throughout their life cycle, especially during old age.

One final, underlying, conclusion of this paper is that elderly poor, in their rural and urban social landscapes, adopted coping strategies to mitigate under-nourishment, destitution and distress, by employing a combination of resources and assistance from the household, community bodies and public charitable institutions, in a complementary way. Thus they were able to reduce the risk incumbent in reliance on one sole provider. It was through such flexible survival strategies that the aging poor endeavoured to respond to their daily requirements and also to unforeseen changes in their life circumstances, and at the same time assure themselves that their basic needs during advanced old age would be met. This represented an attempt to hold on, as much as possible, to a measure of control over their lives, within the limitations imposed by health and poverty.

John Chircop is senior lecturer at the Department of History, the University of Malta. 


\section{References}

\section{Published Books and Articles}

[Anon.], An Appeal on behalf of the Widows, Orphans among Corfiotes now suffering, Corfu, 1836.

[Anon.], Storia della Societa 'Medica d'Incoraggimento, Malta, 1845.

Agius de Soldanis, Ghaudex bil-Grajja tieghu, Malta, 1836.

Angas, G. F., A Ramble in Malta and Sicily in the Autumn of 1841, London, 1842.

Anstead, D. T., The Ionian Islands in the Year 1863, London, 1863.

Badger, G. F., Description of Malta and Gozo, Malta, 1838.

Black, Christopher F., Italian Confraternities in the Sixteenth Century, Cambridge, 1989.

Bowen, George, Ithaca in 1850, London, 1851.

Brambilla, Elena, "The Definitions of Citizenship and the Sacramental System of Churches", pp. 75-86 in A. Cimdina, ed., Religion and Political Change in Europe: Past and Present, Pisa, 2000.

Burke, Peter, History and Social Theory, New York, 1996.

Cassar, Paul, Medical History of Malta, Malta, 1964.

Castagna, Lis-Storia ta Malta bil Gzejer Tahha, vol. 1, Malta, 1888.

Chesney, A., Historical Records of the Maltese Corps of the British Army, London, 1897.

Chesney, A., "The Maltese Corps of the British Army", pp. 287-291, in A. MacMillan, ed., Malta and Gibraltar Illustrated, London, 1915.

Chircop, John, "The British Imperial Network in the Mediterranean 1800-1870. A Study of Regional Fragmentation and Imperial Integration", Unpublished Ph.D. thesis, University of Essex, 1997.

Corringan, Dr., Ten Days in Athens with Notes by the Way, London, 1862.

Cremona, A., L'Ospizzju tal-Furjana u l-Erwieh ta' Wied Ghammieq, Malta, 1959.

Davy, John, Notes and Observations on the Ionian Islands and Malta with some remarks on Constantinople, vol. 2, London, 1822.

De Bosset, C.P., Parga and the Ionian Islands: Comprehending a refutation of the various Mis-Statements on the Subjects, London, 1822.

Dixon, Willis, C., The Colonial Administration of Sir Thomas Maitland, London, 1968.

Femia, Joseph V., Gramsci's Political Thought, Oxford, 1981. 
Galea, Joseph, Il-Konfraternita 'tal-Bumbardiera fil-Knisja ta’ Santa Barbara, Malta, 1988.

Goodison, William A., Topographical and Historical Essay upon the Island of Corfu, Leucadia, and Zante, London, 1822.

Groppi, Angela, "Old People and the Flow of Resources Between Generations in Papal Rome, Sixteenth to Nineteenth Centuries", pp. 89-106, in Susannah R. Ottoway, L.A. Botelho and Katharine Kittredge, (eds.), Power and Poverty. Old Age in the Pre-Industrial Past, Connecticut-London, 2002.

Hannell, David, "The Ionian Islands under the British Protectorate. Social and Economic Problems", Journal of Modern Greek Studies, 7 (1989), 105-132.

Hennen, John, Sketches of the Medical Topography of the Mediterranean.

Comprising an Account of Gibraltar, the Ionian Islands and Malta, London, 1830.

Herzfeld, Michael, The Poetics of Manhood: Contest and Identity in a Cretan Mountain Village, Princeton, 1985.

Holland, H., Travels in the Ionian Isles, Albania, Thessaly, Macedonia \&o. during the years 1812 and 1813, London, 1815.

Jervis-White, Henry Jervis, History of Corfu and of the Republic of the Ionian Islands, London, 1852.

Johnson, Paul, "Historical readings of Old Age and Ageing", pp. 1-11, in Paul Johnson and Pat Thane, (eds.), Old Age from Antiquity to Post-modernity, London, 1998.

Kendrick, T. C., The Ionian Islands. Manners and Customs, London, 1822.

Kimber, W., Edward Lear in Greece. Journals of a Landscape Painter in Greece and Albania, London, 1965.

Kirkwall, Viscount, Four Years on the Ionian Islands, their Political and Social Conditions with a History of the British Protectorate, vol. 2, London, 1864.

Laslett, P. and Wall, R., Household and family in Past time, Cambridge, 1972.

Lenoci, L. B., "Il Culto del SS. Sacramento in due statuti confratelli meridionali", Archivio Storico Pugliese, 39 (1986), 161-183.

Malcolm, A., Letters of an Invalid from Italy and Malta, London, 1897.

Montgomery, Martin R., History of the British Possessions in the Mediterranean, London, 1837.

Montgomery, Martin R., History of the British Empire, Comprising the areas, agriculture, commerce of each colony: Possessions in Europe, London, 1843, vol. 4, London, 1852.

Napier, Charles J., Memoir on the Roads of Cephalonia, London, 1825.

Napier, Charles J., The Colonies: treating of their value generally and of the Ionian Islands in particular, London, 1833.

Leake, W.M., Travels in Northern Greece, vol. 4, London, 1835.

Mansur, Fatima, Bodrum. A Town in the Aegean, London, 1972. 
Lunzi, F., Della Conditione Politica delle Isole Ionie sotto il Dominio Veneto, Venezia, 1858 [fasc. repr. 1969].

Lushington, Mrs.C., Narrative of a Journey from Calcutta to Europe in the Years 1827 and 1829, London, 1829.

Micallef, R., Origins and Progress of the Government Charitable Institutions in Malta and Gozo, Malta, 1901.

Pallis, A.A., Greek Miscellany. A Collection on Medieval and Modern Greece, Athens, 1964.

Pelling, Margareth and Smith, Richard M., eds., Life, Death and the Elderly. Historical Perspectives, London-New York, 1991.

Pratt, Michael, Britain's Greek Empire. Reflections on the History of the Ionian Islands from the fall of Byzantium, London, 1978.

Resch, Jack, "Poverty, Patriarchy and Old Age: The Households of American Revolutionary War Veterans 1820-1830", pp. 21-47, in Susannah R. Ottoway, L.A. Botelho and Katharine Kittredge, eds., Power and Poverty. Old Age in the Pre-Industrial Past, Connecticut-London, 2002.

Sant Cassia, P. and Bada, Constantina, The Making of the Modern Greek Family: Marriage and Exchange in nineteenth century Athens, Cambridge, 1992.

Spierenburg, Pieter, The Broken Spell. Cultural and Anthropological History of Preindustrial Europe, New Brunswick, 1991.

Stamatopoulos, Nondas, Old Corfu - History and Culture, Corfu, 1993.

Thane, Pat, Old Age in English History: Past Experiences, Present Issues, Oxford, 2000.

Webster, Bullock W., English Governors and Foreign grumblers in Malta in 1864, London-Malta, 1864.

\section{Official Publications and Reports}

British Parliamentary Papers: BPP.1845, vol. XXIX; BPP. 1850, vol. XXIV; BPP., 1852-1853, vol. LXII.

Census of the Maltese Islands: 1851, 1861, 1891.

Ionian Islands Blue Books: 1847, 1863.

Letter to H. E. Duke of Newcastle by Four Elected Members of the Council of Government, Malta, 1864.

Malta Government Gazette: April 1817; October 1846.

Rapporto delle Societa`Caritatevole di Cefalonia, Corfu, 1843.

Regulations of the Charitable Institutions in Malta and Gozo, Malta, 1858.

Reports of the Commissioners Appointed to Inquire into the Affairs of the Island of Malta and of Correspondence thereupon, London, 1838.

Seconda Sessione Del Parlamento degli Stati Uniti delle Isole Jonie tenuta in virtu' della 
Constituzione del 1817. No.XI. Atto del Parlamento che proibisce ai particolari in tutte le Isole degli Stati Uniti delle Isole Jonie, ove esistessero Monti di Pieta', di dar o ricever denari con pegno, Corfu, 1819.

\section{Unpublished Sources in Archives}

\section{Public Record Office, Kew, London}

Colonial Office - Ionian Islands

CO.136/12; CO.136/22; CO.136/93; CO.136/1137; CO.136/124-1846;

CO.136/1309

Colonial Office - Malta

CO.159/39; CO.158/41; CO.158/42.

\section{State Archives Corfu, Greece [SAC.G.]}

'Inventario de Santo Monte di Pieta` 1842-1846', 11/43.

'Commissione Municipale del'Igiene Pubblica, Corfu - Settembre 1850, 11/6.

\section{Rabat National Archives, Malta [RNA.M.]}

"Bandi della Corte di Malta, 1812" 